\title{
Dental Education: Detection of the Prevalence of Oral Lesions in Elderly who use Dental Prosthesis through the Dental Record
}

\author{
Maria Vieira de Lima Saintrain ${ }^{1 *}$, Thâmara Manoela Marinho Bezerra ${ }^{2}$ \\ Thaís Guedes Holanda ${ }^{2}$, Davi Oliveira Bizerril ${ }^{3}$, Lúcio Hélio Pereira de Almeida ${ }^{4}$ \\ ${ }^{* 1}$ DDS, Msc, PhD, Pos-doc in Public Health, Professor of University of Fortaleza - UNIFOR, Brazil \\ ${ }^{2}$ DDS, University of Fortaleza, UNIFOR, Brazil \\ ${ }^{3}$ DDS. Msc. Professor of University of Fortaleza - UNIFOR, Brazil \\ ${ }^{4}$ DDS, Msc by University of Fortaleza \\ mvlsaintrain@yahoo.com.br, thamaramanu@gmail.com, thaisgholanda@hotmail.com, \\ thaisgholanda@hotmail.com,davibizerril@gmail.com,luciohpalmeida@yahoo.com.br
}

\begin{abstract}
:
Introduction: The dental prostheses which the function is to rehabilitate become iatrogenic due to inadequate use.

Objective: To investigate, through records, the prevalence of lesions in oral mucosa of the elderly and its relation with the removable prosthesis.

Methods: Quantitative study based on records of elderly from 60 to 92 years old. From the records of the Dental Clinic of the University of Fortaleza-Ceará, Brazil, we elaborated a form for the collection of data which were analyzed by the Software "Statistical Package for Social Science" - SPSS, version 15 (Chicago, Illinois, USA.).

Results: Among the 756 researched records, 479 belonged to women (63.4\%). We verified that 358 (47.3\%) elderly used removable prosthesis (superior, inferior or both), 138 (18.3\%) had oral lesion. Fungal 59 (42.7\%) and traumatic $48(34.7 \%)$ lesions prevailed. There was statistical significance $(p<0.05)$ between oral lesion and use of prosthesis, oral lesion and type of prosthesis, oral lesion and frequency of use of prosthesis.

Conclusion: Through the records we detected a high prevalence of oral lesions which can be related to the use of inadequate dental prostheses. The records constituted epidemiologic research and student's learning tool, working as a basis for the elaboration of oral health actions to the population.
\end{abstract}

Keywords: Epidemiology; Oral health; Dental prosthetics; Lesion; Elder.

\section{INTRODUCTION}

Brazil has faced a considerable increase in the number of older people ${ }^{1}$, thus, aging became one of the biggest challenges of the contemporary public health ${ }^{2,3}$. The Elderly People National Health Policy ${ }^{4}$ considers elderly, in Brazil, people who are 60 years old or older. It was because of it and the Oral Health National Policy ${ }^{5}$ that the primordial rights to the health of this population were ensured and explicit.

Despite the advances, aging hasn't been fully studied so that it's provided necessary elements to the development of adequate public actions to this population, once the health programs directed to the elderly are still rare ${ }^{6}$. The health professionals and services must be prepared for the work with elderly, which requires interdisciplinary approach ${ }^{7}$, since that, oral factors can aggravate the evolution of systemic diseases and these may endanger the dental work and/or people's quality of life.

Regarding the dental care, for a long time, the elderly were affected by an assistential model, focused on curative and crippling practices ${ }^{8}$. As a consequence of this is the high edentulism rate, proved by the findings of the SB Brasil Project ${ }^{9}$, which found that $39.96 \%$ of the examined elderly from 65 to 74 years old needed total superior and/or inferior prosthesis and $82.75 \%$ already used theses types of dental prostheses. This serious fact is corroborated by a research ${ }^{10}$, in which almost half of the elderly who used prosthesis showed oral lesions. So, investigations on the structural and functional conditions of the prosthesis in use, general health status and the oral hygiene conditions must be conducted in order to propose adequate curative and preventive measures. 
The dental prosthesis recovers the aesthetics and the phonetics and it also substitutes the teeth, aiming to rehabilitate the stomatognathic system ${ }^{11}$. However, many other times, it doesn't work like this, becoming iatrogenic due to laboratorial and clinical errors ${ }^{12}$. The iatrogenesis happens also due to the fact that many prostheses are made by professionals who aren't able to make them. In a study with elderly who used removable prosthesis, $54.2 \%$ reported that the prostheses weren't made by dentistsurgeons, harming the stomatognathic system because of unsatisfactory removable prostheses, causing pain, problem in use, discomfort and oral lesions ${ }^{13,14}$.

The inadequate or even the lack of guidance of the dentist-surgeon regarding the way and frequency of using it and the hygiene methods used in the prostheses can contribute to the occurrence of several oral pathologies such as stomatitis, traumatic ulcers and inflammatory fibrous hyperplasia ${ }^{14,15}$.

Concerning to this problematic, this work aimed to identify, through records, the prevalence of oral lesions and their relation to the use of removable prostheses.

\section{MeTHODS}

It is a quantitative and descriptive study. The research universe was made up of all the 1361 records in the file of elderly patients who were treated in the Clinic of the Dentistry Course of the University of Fortaleza - UNIFOR from 1998 to 2006. However, the sample was simplified into 756 records because 605 didn't meet the pre-established inclusion criteria, such as record with information about the object study (oral lesions and use of dental prosthesis). This period culminates with the performance of the Dental Clinic in 10 years of foundation of the Dentistry Course, inaugurated in 1996.

The Dental Clinic of UNIFOR receives patients by spontaneous demand and is a reference in the State of Ceará. After the classification of the clinical profile, the patients are included in the System of Academic Information and sent to different assistance sectors.

Considering the records structure, it was elaborated a form as an instrument for data collection: Patient's identification (age, sex, marital status); socioeconomic level (income, schooling); use of dental prosthesis (type, hygiene and time of use) and soft tissues lesions, detected at the moment of the anamnesis.

The data collection was performed by two researchers and Dentistry students (TMMB and TGH) who were trained, using 10 randomly selected records, referent to the standardization of the investigated variables. For the database, it was used the Software "Statistical Package for Social Science" - SPSS, version 15 (Chicago, Illinois, USA). The data were organized in tables and in the descriptive analysis of the quantitative variables; we used measures of central tendency (arithmetic mean, standard deviation and frequency distribution). It was used Pearson's Chi-square distribution and Fisher's Exact Test for comparisons, considering statistically significant the analyses with $\mathrm{p}<0.05$.

An authorization term was signed by the legal depository, responsible for the patients` records. With no conflict of interest, the project was approved by the Ethics Committee of the University of Fortaleza, Opinion No. 069/2007.

\section{RESUlTS}

From the 756 researched records, 479 belonged to women $(63.4 \%)$ and 277 to men (36.6\%), whose age ranged from 60 to 92 years old (mean 66.99 years, $\mathrm{SD} \pm 6.05$ ).

Among the socioeconomic data, some stand out: 346 (46.2\%) white elderly, 366 (48.4\%) married, 320 $(42.3 \%)$ retired, $341(45.1 \%)$ incomplete elementary school and $547(72.4 \%)$ with an income up to two minimum wages.

The women [267 (72.4\%)] used more the prosthesis when compared to men [102 (27.6\%] with statistical significance Chi-square $=29.802 \mathrm{p}=0.0001$.

Among all the evaluated records, it was detected a prevalence of $18.3 \%$ of patients (138) with oral lesions.

From all the records ( $\mathrm{n}=756), 358(47.3 \%)$ belonged to patients who used removable prosthesis and fixed prosthesis (superior, inferior and/or both), showing in table 1 that the total bimaxilary and total superior dental prostheses are the most used. (Table 1)

In table 2, we see that most of the patients became edentulous during the time from 21 to 40 years old, culminating with a longer use of the prostheses, although the more recent prostheses, mostly, have been used for 5 to 10 years. 
Dental Education: Detection of the Prevalence of Oral Lesions in Elderly who use Dental Prosthesis through the Dental Record

In table 3, it's evidenced statistical significance between oral lesion and the use of Prosthesis $(\mathrm{p}<0.05)$ and also in relation to the type and frequency of use of the dental prosthesis.

The prostheses, total inferior, singly, and partial bimaxilary don't show statistical significance in relation to oral lesions.

It was computed hygiene methods: mechanical - toothbrush, dental floss, toothpick with cotton, steel wool, pumice stone, brush and toothbrush, and, chemical - coconut soap, laundry soap, bath soap, detergent, hypochlorite, sodium bicarbonate, toothpaste, corega tabs, mouthwash, water with salt, clove and lemon.

To chemically clean the prosthesis showed lower prevalence of oral lesions, however without statistical significance.

Table1. Types of dental prostheses of the 369 elderly who use prosthesis assisted in the Dentistry Course in the period from 1998 to 2006. UNIFOR - Fortaleza, 2009

\begin{tabular}{|l|c|c|}
\hline Type of dental prosthesis & $\mathrm{N}$ & $\%$ \\
\hline Total Bimaxilary & 120 & 32.5 \\
\hline Total Superior & 121 & 32.8 \\
\hline Total Inferior & 4 & 1.1 \\
\hline Partial Bimaxilary & 66 & 17.9 \\
\hline Partial Superior & 34 & 9.2 \\
\hline Partial Inferior & 58 & 15.7 \\
\hline Fixed Bimaxilary & 25 & 6.8 \\
\hline Fixed Superior & 2 & 0.5 \\
\hline Fixed Inferior & 3 & 0.8 \\
\hline
\end{tabular}

Table2. Distribution of frequency referring to the time of edentulism, use of prosthesis and time of the current prosthesis of the patients in the research. UNIFOR, Fortaleza-CE, 2009

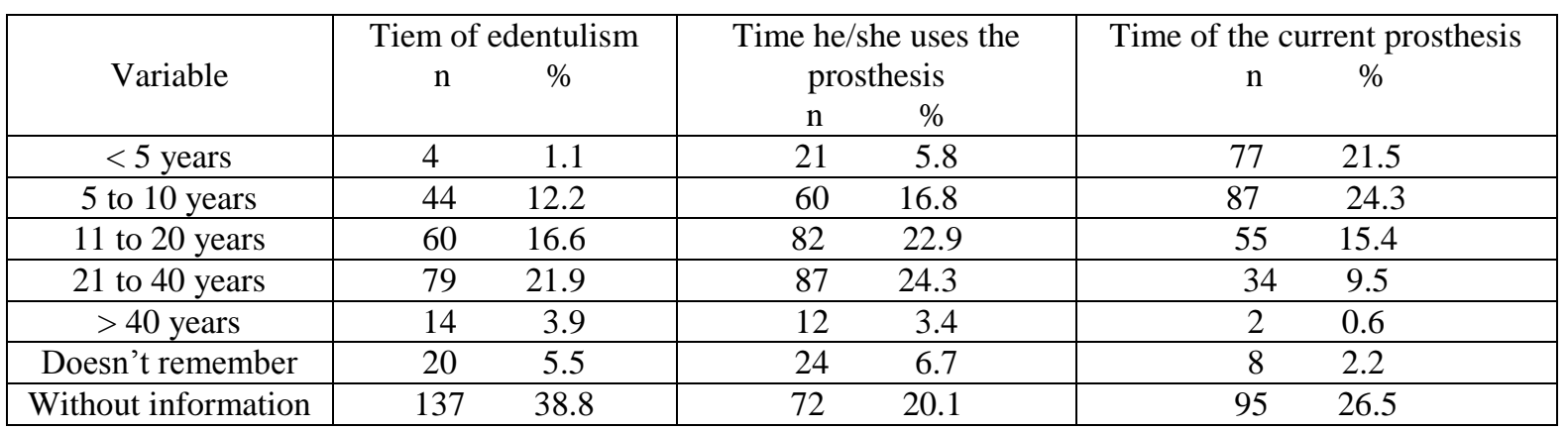

Table3. Oral lesion of the 138 patients who use removable prosthesis, according to type and frequency of use. Fortaleza, 2009

\begin{tabular}{|c|c|c|c|c|c|}
\hline & \multicolumn{4}{|c|}{ Oral lesion } & \multirow[b]{2}{*}{$P$} \\
\hline Variable & $\begin{array}{l}\text { Yes } \\
\text { No. }\end{array}$ & $\%$ & $\begin{array}{l}\text { No } \\
\text { No. }\end{array}$ & $\%$ & \\
\hline \multicolumn{6}{|c|}{ Uses prosthesis } \\
\hline Yes & 98 & 26.6 & 270 & 73.4 & $0.0001 *$ \\
\hline No & 40 & 10.3 & 348 & 87.7 & \\
\hline \multicolumn{6}{|c|}{ Type of prosthesis } \\
\hline \multicolumn{6}{|c|}{ Total bimaxilary } \\
\hline Yes & 48 & 40.7 & 70 & 59.3 & $0.0001 *$ \\
\hline No & 90 & 14.1 & 548 & 85.9 & \\
\hline \multicolumn{6}{|c|}{ Total superior } \\
\hline Yes & 33 & 27.3 & 88 & 72.7 & $0.005 *$ \\
\hline No & 105 & 16.5 & 530 & 83.5 & \\
\hline \multicolumn{6}{|c|}{ Partial inferior } \\
\hline Yes & 18 & 31.6 & 39 & 68.4 & $0.011 * *$ \\
\hline No & 120 & 17.2 & 579 & 82.8 & \\
\hline \multicolumn{6}{|c|}{ Frequency of use } \\
\hline Continuous & 77 & 27.3 & 205 & 72.7 & $0.0001 *$ \\
\hline Sporadic & 61 & 12.9 & 413 & 87.1 & \\
\hline
\end{tabular}

*Chi-square distribution, ** Fisher's test 


\section{DISCUSSION}

\subsection{The Socio-Economic Scenario in which the Elderly are Inserted}

The research showed that the elderly women look more for dental assistance than men. To Alexandre et $a{ }^{16}{ }^{16}$, this happens because the men only look for dental assistance when they already have some kind of pathology.

It was observed a low schooling, and it's possible to imply that the lack of information causes the unawareness of the individual health problem and of the ways to solve it, leaving the elderly without access to information relating to scientific findings and recommendations of preventive and self-care measures, which are necessary to perform important oral health tasks ${ }^{17}$. Thus, attempts to improve public health are jeopardized if there's no focus on education ${ }^{18}$. The low schooling implies a lower income which results in the priority of the elderly to meet their basic needs first rather than oral health.

\subsection{Oral Pathologies in Elderly and their Direct Relation with the use of Removable Prostheses}

In this study, the records subsidized the acquisition of a databank of which the epidemiological variables could identify the oral health condition of the elderly assisted in the Clinic of the University of Fortaleza.

It was detected the following oral lesions in 138 patients: fungal lesions (Prosthetic stomatitits, candida and angular cheilitis), lesions due to trauma (inflammatory fibrous hyperplasia, keratosis, fibromas, aphtous ulcer and nicotinic stomatitis), malign and Pre-malign lesions (epidermoid carcinoma, leukoplakia and actinic cheilosis), non-pathological alterations (coating tongue, fissured tongue, geographic tongue and Fordyce's spots), among others.

The fungal $(42.7 \%)$ and traumatic (34.7\%) lesions were computed as most prevalent ones, data which is corroborated in a similar study ${ }^{14}$. In some patients it was observed more than one oral lesion. Associations of oral pathologies in elderly were found in similar studies ${ }^{14,19,20}$.

The stomatitis is the most present lesion in the ones who use dental prosthesis, occurring mainly, because of functional factors ( deficiency in the occlusion, vertical dimension of occlusion, retention, dynamics and statics stability) and qualitative factors (time of edentulism, time of use of the prostheses, age, conservation, continuous use, dental plaque and bad oral hygiene) ${ }^{11,15,21}$.

Regarding the mucosa lesions associated to the use of removable prosthesis, the frequency found (26.6\%) was inferior when compared to the ones reported by Mojica et al. ${ }^{20}$. This difference comes, probably, from records inadequately filled and from the lack of semiologic examination of the oral tissues, which sometimes is not made or understood by some professionals. About the records who presented inadequate information, it is important to emphasize that its filling is indispensable, because besides being tools for epidemiologic research, its lack of information may jeopardize the patient's follow-up.

\subsection{Use of Dental Prosthesis in Brazil: Consequence of A Bad Oral Health Policy}

In this research, total bimaxillary dental prosthesis was the most used by the elderly (Table 1). These results are corroborated by project SB Brazil9 Which found in the Brazilian population, in the age group from 65 to 74 years old, $37,5 \%$ rehabilitated by total lower dental prosthesis and $63,4 \%$ by the upper dental prosthesis. This implies that, at some moment, these individuals had access to the dental care services, independently of its quality. However, the access opportunity must not be confused with care complexity or the demand of public services for this kind of rehabilitation ${ }^{22}$.

The total superior prostheses were used more than the inferior (32.8\% and $1.1 \%$, respectively). Such results, in the conception of researchers ${ }^{22}$, appear to be a bigger preoccupation with facial aesthetics, once the superior teeth are usually more visible in the smile than the inferior and the reason that the inferior prostheses cause discomfort sensation for they are more difficult to adapt.

In table 3, it's verified that the elderly use the same prosthesis for a long time, certifying a bigger proportion from 21 to 40 years old $(21.9 \%$ ), with the use of the current prosthesis from 5 to 10 years (24.3\%), condition that is corroborated by Peracini et al. ${ }^{11}$ in which patients used the current prosthesis for more than 10 years. The time of use of the dental prosthesis influences on the essential factors for the harmonic functioning of the stomatognathic system, such as retention, stability and 
occlusal relation $^{23}$, however, the lifetime of the prostheses depend on the clinical evaluation and the effective care in relation to the hygiene and its conservation.

The appearance of oral lesions is related to unsatisfactory prostheses, the ways to use them and hygiene care with them ${ }^{11,14}$. However, the presence of the prosthesis itself is not a determinant for the emerging of oral pathologies, which can be avoided through regular control consultations ${ }^{15}$, and adequate guidance to patients, for which the professionals must be aware of its importance in their graduation.

\subsection{Time of use of the Dental Prostheses by the Elderly}

The long time use of the current prostheses can be explained by the elderly adaptive capacity, along with the difficulties of access to public dental treatment and the cost of prosthetic rehabilitation in private clinics ${ }^{23}$. This information makes us believe that the oral rehabilitation is directly related to the cultural and socioeconomic condition of the individual and the society where he/she lives.

Most of the elderly who used continuously the prosthesis had oral lesion, as it's verified in table 3 , and among the ones who slept with the dental prosthesis, $28.2 \%$ had oral lesions. Superior datum was described by Kossioni ${ }^{24}$, whose study reported that the continuous use of dental prosthesis is the main risk factor for prosthetic stomatitis. This information is an important resource for the Dentistry professional who shall be aware to pass on notions of Health Education, e.g., to tell the patients to not sleep with the prosthesis ${ }^{12}$, considering that its removal causes the relaxation and rest of the tissues, while the tongue, cheek, lips and saliva exert cleaning function ${ }^{25}$.

\subsection{Dental Prosthesis Hygiene: A Habit to be Developed}

The elderly who chemically cleaned the prosthesis showed lower prevalence of oral lesions. The sodium hypochlorite in $2.25 \%$ (bleach) has a bactericide and fungicide action, reduces the accumulation of biofilm, organic deposits, removes spots and inhibits calculus formation, showing this way, efficiency in cleaning the removable prostheses ${ }^{26,27}$, despite the disadvantage of the dimming and corrosion of the metal components and the brightening of the acrylic resin.

Authors ${ }^{28}$ recommend that the dental prosthesis shall be immersed in a solution of $15 \mathrm{ml}$ of sodium hypochlorite (2.25\%) with $200 \mathrm{ml}$ of water for 10 minutes every 4 days, along with brushing, because a single method isn't capable to remove all the biofilm in the dental prosthesis.

The oral cavity and prosthetic hygiene must be well explained to the patient ${ }^{25}$, because the bad prosthetic hygiene is aggravated when patients don't receive instructions about oral hygiene or how to take care of their prostheses ${ }^{22}$. Researchers observed that most of the patients didn't receive instructions from the dentist-surgeon about the needs and methods of prosthetic hygiene ${ }^{11}$.

According to literature, the toothbrushes shall not be used as substitutes of the ones which are adequate to clean the prosthesis, because they have an inadequate shape, raising difficulties to clean the sulci ${ }^{29}$.

The findings of this research confirm the lack of public policies directed to the promotion of the elderly oral health and reveal the consequences of the Brazilian radical and crippling Dentistry of the past, when only the school people had preventive treatments ${ }^{30}$.

A new perspective for the oral health of the Brazilian elderly population emerged with the insertion of Dentistry in the Family Health Program (FHP) and the insertion of the program Brasil Sorridente, by the Ministry of Health in Brazil, which pledge benefits of preventive actions, as well as oral rehabilitation ${ }^{30}$.

The dental education, as well as concrete and permanent public policies of preventive, curative, educative and rehabilitating actions must have a place in specificities directed to the elderly population in order to improve its quality of life $\mathrm{e}^{22}$.

It's emphasized, in the proposals for a better follow-up of patients by Dentistry professionals, the need for more rigor in the records information, for they constitute the basis for information on educative and preventive care, and for the improvement of the oral health condition of the population. 


\section{Conclusion}

Through the records, it was conceived a high prevalence of $18.3 \%$ of patients with oral lesions; the use of inadequate dental prostheses increases the occurrence of these pathologies; the correct handling of the records constitutes an important tool for epidemiologic research, as well as for patient's followup.

\section{REFERENCES}

[1] IBGE (Instituto Brasileiro de Geografia e Estatística). Sinópse do Censo Demográfico 2010. Ministério do Planejamento e gestão, Brasil. Available at: C:LDocuments and Settings\Administrador|Desktop\IBGE Censo 2010. mht. Accessed April 06, 2016.

[2] Veras R. Envelhecimento populacional contemporâneo: demandas, desafios e inovações. Revista Saúde pública 2009; 43(3):548-54.

[3] Lima-Costa MF, Veras R. Saúde pública e envelhecimento. Cad. Saúde Pública 2003; 19(3):7001.

[4] Brasil. Ministério da Saúde. Portaria no 2528 de 19 de outubro de 2006. Aprova a Política Nacional de Saúde da Pessoa Idosa. Brasília: Ministério da Saúde; 2006.

[5] Brasil. Política Nacional de Saúde Bucal do Brasil. Registro de uma conquista histórica. In: Saúde, OPAD. (Ed.). Desenvolvimento de sistemas e serviços de saúde, 2006.

[6] Garrido R, Menezes P. O Brasil está envelhecendo: boas e más notícias por uma perspectiva epidemiológica. Revista Brasileira de Psiquiatria 2002; 24:3-6.

[7] Saintrain MVL, Vieira LJES. Saúde bucal do idoso: abordagem interdisciplinar. Ciências \& Saúde Coletiva 2008; 13(4):1127-32.

[8] Moreira RS, Nico LS, Tomita NE, Ruiz T. A saúde bucal do idoso brasileiro: revisão sistemática sobre o quadro epidemiológico e acesso aos serviços de saúde bucal. Caderno de Saúde Pública 2005; 21(6):1665-75.

[9] Ministério da Saúde (BR). SBBrasil 2010: Pesquisa Nacional de Saúde Bucal Available at: www.saúde.gov.br Accessed 2016, Jan 15.

[10] Mesas AE, Andrade SM, Cabrera MAS. Condições de saúde bucal de idosos de comunidade urbana de Londrina, Paraná. Revista Brasileira de Epidemiologia 2006; 9(4):471-80.

[11] Peracini A, Andrade IM, Paranhos HFO, Silva CHL, Souza RF. Behaviors and hygiene habits of complete denture wearers. Braz Dent J 2010; 21(3):247-52.

[12] Costa MM, Oliveira JEC, Prado CJ, Reis SMAS. As próteses removíveis e as iatrogenias evitáveis. ROBRAC 1997; 6(21):11-3.

[13] Bomfim IPR, Soares DG, Tavares GR, Santos RC, Araújo TP, Padilha WWN. Prevalência de lesões de mucosa bucal em pacientes portadores de prótese dentária. Pesq Bras Odontoped Clin Integr 2008; 8(1):117-121.

[14] Ferreira, RC, Magalhães CS, Moreira, AN. Oral mucosal alterations among institutionalized elderly in Brazil. Braz Oral Res 2010; 24(3): 296-302.

[15] Sadig W. The denture hygiene, denture stomatitis and role dental hygienist. Int J Dent Hyg 2010; 8(3): 227-31.

[16] Alexandre GC, Nadanovsky P, Lopes CS, Faerstein E. Prevalência e fatores associados à ocorrência da dor de dente que impediu a realização de tarefas habituais em uma população de funcionários públicos no Rio de Janeiro, Brasil. Cad Saúde Pública 2006; 22(5):1073-78.

[17] Rudd RMSPH, Horowitz AM. The Role of Health Literacy in Achieving Oral Health for Elders. Journal of Dental Education 2005; 69 (9): 1018-1021.

[18] Monti LM, Justi, MM, Farjado RS, Zavanelli AC. Análise comparada da saúde bucal do idoso na cidade de Araçatuba. Rev Bras Geriatr Gerontol 2006; 9(2):35-47.

[19] Simões ACA, Carvalho, DM. The reality of the oral/dental health of the elderly in the Brazilian Southeast. Cienc Saude Colet 2011; 16(6):2975-82.

[20] Mujica V, Rivera H, Carrero M. Prevalence of oral soft tissue lesions in an elderly venezuelan population. Med Oral Patol Oral Cir Bucal 2008; 13(5):270-4.

[21] Neville BW, Damm DD. Patologia Oral e Maxilofacial. 3.ed. Rio de Janeiro: Elsevier; 2009. 
[22] Crispim AJ, Saupe R, Boing AF. Perfil epidemiológico do uso e necessidade de prótese e de alterações de tecidos moles bucais em idosos de uma comunidade de Itajaí-SC. Arq Catarinenses de Med 2009; 38(2):52-7.

[23] Cabrini J, Fais LMG, Compagnoni MA, Mollo Junior FA, Pinelli LAP. Tempo de uso e qualidade das próteses totais - uma análise crítica. Cien Odontol Bras 2008; 11(2):78-85.

[24] Kossioni AE. The prevalence of denture stomatitis and its predisposing conditions in an older Geek population. Gerodontology 2011; 28:85-90.

[25] Gonçalves LPV et al. Estudo clínico das lesões de mucosa provocadas pelo uso de próteses removíveis. RBO 1995; 52(2):9-12.

[26] Coelho Vieira AP, Senna PM, da Silva WJ, Del Bel Cury AA. Long-term efficacy of denture cleansers in preventing Candida ssp biofilm recolonization on liner surface. Braz Oral Res 2010; 24(3):342-8.

[27] Barnabé W, de Mendonça Neto T, Pimenta FC, Pergoraro L, Fand Scolaro JM. Efficacy of sodium hypochlorite and coconut soap used as disinfecting agents in the reduction of denture stomatitis, Streptococcus mutans and Candida albicans. Journal of Oral Rehabilitation 2004; 31:453-9.

[28] Silva UH, Faria DLB. Propedêutica odontológica, $2^{\mathrm{a}}$ ed. João Pessoa: Idéia, 2010

[29] Silva RJ, Seixas ZA. Materiais e métodos de higienização para próteses removíveis. Int J Dent 2008; 7(2):125-132.

[30] Gaião LR, Almeida MEL, Heukelbach J. Perfil epidemiológico da cárie dentária, doença periodontal, uso e necessidade de prótese em idosos residentes em uma instituição na cidade de Fortaleza, Ceará. Rev Bras Epidemiol 2005; 8(3):316-23. 